\title{
Recent advances in brucellosis
}

The United Kingdom was declared officially free of bovine brucellosis caused by Brucella abortus, the only indigenous form of the disease, in 1981. Since then, the disease has also been eradicated from Australia, Canada and New Zealand and is now uncommon in most European Countries and the USA. On the other hand, with the relaxation of state control the disease is increasing in several countries of the former USSR in which it was previously well controlled. B. melitensis infection is still widespread around the Mediterranean littoral and has recently undergone a resurgence in Malta. It has also established itself as a major problem in cattle in Israel and countries of the Arabian peninsula, in which it was formerly confined to sheep and goats.

Transmission to man still occurs through consumption of unpasteurised dairy produce, direct contact with infected animals, or indirectly by environmental exposure. Human cases are occasionally imported into the UK and other countries that are free of indigenous infection. Diagnosis is not difficult if the level of suspicion is high and the presentation is typical, but the varied and sometimes misleading manifestations of localised, sub-acute or chronic infection, mean that cases may be misdiagnosed [1].

Although B. melitensis accounts for most recorded cases, B. abortus and B. suis cause substantial morbidity in countries in which they persist in domestic animals, notably in Asia and Latin America. $B$. canis rarely causes overt human disease, and B. neotomae and B. ovis have not been identified as causes of disease in man. Anecdotal evidence suggests that strains of Brucella species that have been isolated from marine animals in the UK and USA $[2,3]$ may be pathogenic for man.

\section{Molecular genetics}

The average size of the genome is $2.37 \times 10^{3} \mathrm{MDa}$, with a DNA G + C content of $58-59 \mathrm{~mol} \%$. All types show $>95 \%$ homology in DNA-DNA pairing studies, justifying the nomination of Brucella as a monospecific genus [4]. However, the suggestion that all types should be regarded as biovars of $B$. melitensis has met with resistance on practical grounds and the old nomenclature has been retained. Seven biovars are recognised for B. abortus (1-6 and 9), three for B. melitensis (1-3), and five for $B$. suis $(1-5)$ [5]. The other species have not been differentiated into biovars although variants exist. The strains isolated from marine animals form a separate group and should be designated as a new nomenspecies.

Restriction fragment patterns produced by infrequently cutting endonucleases support the differentiation of the nomen species [6]. Restriction endonuclease analysis has generally been unsuccessful for strain differentiation, but amplification and sequencing of selected genes has provided evidence of polymorphism in a number of genes including omp 2, dnaK, htr and ery (the erythrulose-1-phosphate dehydrogenase gene) [79]. The omp 2 gene is believed to determine dye sensitivity, one of the traditional typing methods for biovar differentiation. Its polymorphism and the capacity for post-translational modification of its product may explain the tendency for variation in dye sensitivity patterns even within nomen species. A 7.2-kb deletion in the ery gene in B. abortus strain 19 [9] may explain the erythritol sensitivity of this strain which is a major factor in its attenuation.

The genome of Brucella contains two chromosomes of 2.1 and $1.5 \mathrm{Mb}$, respectively. Both replicons encode essential metabolic and replicative functions and hence are chromosomes, not plasmids $[10,11]$. Natural plasmids have not been detected in Brucella, although transformation has been effected by wide host range plasmids following conjugative transfer or electroporation [12].

\section{Antigenic structure}

The major surface antigen of smooth phase strains is a lipopolysaccharide (S-LPS) with a lipid A containing: two types of aminoglycose; distinctive fatty acids, but excluding $\beta$-hydroxymyristic acid; a core region containing glucose, mannose and quinovosamine; and an $\mathrm{O}$ chain comprising a homopolymer of c. 100 residues of 4-formamido-4,6-dideoxymannose which are linked predominantly $\alpha-1,2$ in A epitope dominant strains, but with every fifth residue linked $\alpha-1,3$ in $\mathrm{M}$ dominant strains. Types that express both epitopes to a similar extent produce both LPS types [13]. The presence of 4-amino,4,6 dideoxymannose in the LPS is also responsible for the antigenic cross-reactivity between Escherichia hermanni, E. coli O157, Salmo- 
nella $\mathrm{O} 30$, Vibrio cholerae $\mathrm{O} 1$, and Yersinia enterocolitica O9 LPS [13].

Numerous protein antigens have been characterised. Some are recognised by the immune system during the course of infection and are potentially useful in diagnostic tests. The ribosomal proteins $\mathrm{L} 7 / \mathrm{L} 12$ stimulate cell-mediated responses and elicit delayed hypersensitivity responses as components of brucellins [14]. They seem to be important in the induction of protective immunity [15].

\section{Mechanisms of pathogenicity}

The S-LPS is a major determinant of virulence and dominates the antibody response. It is the main component responsible for conferring incomplete and short-term protection against infection in passive transfer experiments with monoclonal and polyclonal antibodies [16]. The elimination of virulent brucellae depends upon activated macrophages and hence requires development of Thl type cell-mediated immunity. Brucella LPS is a relatively poor inducer of interferon- $\gamma$ and tumour necrosis factor- $\alpha$, both essential for the elimination of the organism $[17,18]$. Unusually, it is an effective inducer of interleukin 12, which stimulates Th1 type responses and is closely correlated with interferon- $\gamma$ production. Other important virulence factors include: the production of adenine and guanine monophosphate which inhibit phagocyte function [19]; $\mathrm{Cu}-\mathrm{Zn}$ superoxide dismutase which is believed to eliminate reactive oxygen intermediates in phagocytes [20]; and a number of stressinduced proteins which promote survival within macrophages [21].

\section{Diagnosis}

The clinical picture is often misleading and the disease may present with gastrointestinal, respiratory, dermal or neurological manifestations as well as those considered more typical of brucellosis [1,22]. Diagnosis should always be supported by laboratory tests. Blood culture is often effective during the acute phase, but allowance should be made for the relatively slow growth of the organism; the lysis concentration method gives the best results [23]. Presumptive identification is made on the basis of morphological, cultural and serological properties. Reliance should not be placed on commercial gallery-test systems as they may misidentify Brucella spp. as Moraxella phenylpyruvica, with serious consequences [24]. Polymerase chain reaction (PCR) methods with random or selected primers need standardisation and further evaluation, especially for chronic disease [25]. Similarly, antigen detection methods are potentially useful but have not been validated. Enzyme immunoassay (ELISA) is widely used for serological diagnosis. $\operatorname{IgA}$ and IgG antibodies seem the most useful indicators of active infection $[26,27]$. Western blotting against selected cytoplasmic proteins may allow differentiation of active from past or subclinical infection [28].

\section{Treatment and prevention}

The recommended treatment for acute brucellosis in adults is rifampicin $600-900 \mathrm{mg}$ and doxycycline $200 \mathrm{mg}$ daily for a minimum of 6 weeks [29], although the combination of intramuscular streptomycin with an oral tetracycline is claimed to give fewer relapses [30]. There is evidence of antagonism between rifampicin and tetracyclines, but the two regimens give very similar results if adequately prolonged. Quinolones in combination with rifampicin also seem to be effective [31]. Controlled clinical trials with other antibiotics, including new macrolides, have either given inferior results or have been too limited for proper evaluation. Meningo-encephalitis or endocarditis require combination therapy with rifampicin, a tetracycline and an aminoglycoside. Rifampicin is the treatment of choice for uncomplicated disease in children; co-trimoxazole is an alternative but is less effective.

A safe and effective vaccine for use in man is not yet available, but recent work on purE mutants of $B$. melitensis has given encouraging results in animals and may lead to clinical trials [32]. Prevention is dependent upon the control of the disease in animal hosts, effective heat treatment of dairy produce and hygienic precautions to prevent occupational exposure.

M. J. CORBEL

Division of Bacteriology, National Institute for Biological Standards and Control, Potters Bar EN 63 QG, Hertfordshire

\section{References}

1. Young EJ. An overview of human brucellosis. Clin Infect Dis 1995; 21: 283-290.

2. Ross HM, Foster G, Reid RJ, Jahans KL, MacMillan AP Brucella species infection in sea mammals. Vet Rec 1994; 134: 359.

3. Ewalt DR, Payeur JB, Martin BM, Cummins DR, Miller WG. Characteristics of a Brucella species from a bottlenose dolphin (Tursiops truncatus). J Vet Diag Invest 1994; 6: 448-452.

4. Verger J-M, Grimont F, Grimont PAD, Grayon M. Brucella, a monospecific genus as shown by deoxyribonucleic acid hybridization. Int J Syst Bacteriol 1985; 35: 292-295.

5. Corbel MJ, Morgan WJB. Genus Brucella Meyer and Shaw $1920,173^{\mathrm{AL}}$. Bergey's Manual of systematic bacteriology, vol. 1. Baltimore, Williams and Wilkins. 1984: 377-388.

6. Allardet-Servent A, Bourg G, Ramuz M, Pages M, Bellis M, Roizes G. DNA polymorphism in strains of the genus Brucella. J Bacteriol 1988; 170: 4603-4607.

7. Ficht TA, Bearden SW, Sowa BA, Adams LG. DNA sequence and expression of the 36-kilodalton outer membrane protein gene of Brucella abortus. Infect Immun 1989; 57: 3281-3291.

8. Cellier MFM, Teyssier J, Nicolas M, Liautard JB, Marti J, Sri Widada J. Cloning and characterization of the Brucella ovis heat shock protein DnaK functionally expressed in Escherichia coli. J Bacteriol 1992; 174: 8036-8042.

9. Sangari FJ, García-Lobo JM, Agüero J. The Brucella abortus 
vaccine strain B19 carries a deletion in the erythritol catabolic genes. FEMS Microbiol Lett 1994; 121: 337-342.

10. Michaux S, Paillisson J, Carles-Nurit M-J, Bourg G, AllardetServent A, Ramuz M. Presence of two independent chromosomes in the Brucella melitensis $16 \mathrm{M}$ genome. J Bacteriol 1993; 175: 701-705.

11. Jumas-Bilak E, Maugard C, Michaux-Charachon S et al. Study of the organization of the genomes of Escherichia coli, Brucella melitensis and Agrobacterium tumefaciens by insertion of a unique restriction site. Microbiology 1995; 141: $2425-2432$.

12. Rigby CE, Fraser AD. Plasmid transfer and plasmid-mediated genetic exchange in Brucella abortus. Can J Vet Res 1989; 53 : $326-330$

13. Perry MB, Bundle DR. Lipopolysaccharide antigens and carbohydrates of Brucella. In: Adams LG (ed) Advances in brucellosis research. Austin, Texas A \& M University. 1990: 76-88.

14. Bachrach G, Banai M, Bardenstein S, Hoida G, Genizi A, Bercovier $\mathrm{H}$. Brucella ribosomal protein $\mathrm{L} 7 / \mathrm{L} 12$ is a major component in the antigenicity of Brucellin INRA for delayedtype hypersensitivity in Brucella-sensitized guinea-pigs. Infect Immun 1994; 62: 5361-5366.

15. Oliveira SC, Splitter GA. Immunization of mice with recombinant $\mathrm{L} 7 / \mathrm{L} 12$ ribosomal protein confers protection against Brucella abortus infection. Vaccine 1996; 14: 959-962.

16. Dubray G. Protective antigens in brucellosis. Ann Inst Pasteur Microbiol 1987; 138: 84-87.

17. Zhan Y, Kelso A, Cheers C. Differential activation of Brucellareactive $\mathrm{CD}^{+}$cells by Brucella infection or immunization with antigenic extracts. Infect Immun 1995; 63: 969-975.

18. Caron E, Peyrard T, Köhler S, Cabane S, Liautard J-P, Dornand J. Live Brucella spp. fail to induce tumor necrosis factor alpha excretion upon infection of U937-derived phagocytes. Infect Immun 1994; 62: 5267-5274.

19. Canning PC, Roth JA, Deyoe BL. Release of 5 '-guanosine monophosphate and adenine by Brucella abortus and their role in the intracellular survival of the bacteria. $J$ Infect Dis 1986; 154: $464-470$.

20. Bricker BJ, Tabatabai LB, Judge BA, Deyoe BL, Mayfield JE. Cloning, expression, and occurrence of the Brucella $\mathrm{Cu}-\mathrm{Zn}$ superoxide dismutase. Infect Immun 1990; 58: 2935-2939.

21. Lin J, Ficht TA. Protein synthesis in Brucella abortus induced during macrophage infection. Infect Immun 1995; 63: 1409 1414.

22. Madkour MM. Brucellosis. London, Butterworths. 1989.

23. Kolman S, Maayan MC, Gotesman G, Roszenstajn LA, Wolach $B$, Lang R. Comparison of the Bactec and lysis concentration methods for recovery of Brucella species from clinical specimens. Eur J Clin Microb Infect Dis 1991; 10: 647-648.

24. Luzzi GA, Brindle R, Sockett PN, Solera J, Klenerman P, Warrell DA. Brucellosis: imported and laboratory-acquired cases, and an overview of treatment trials. Trans $R$ Soc Trop Med Hyg 1993; 87: 138-141.

25. Matar GM, Khneisser IA, Abdelnoor AM. Rapid laboratory confirmation of human brucellosis by PCR analysis of a target sequence on the 31-kilodalton Brucella antigen DNA. J Clin Microbiol 1996; 34: 477-478.

26. Araj GF, Lulu AR, Mustafa MY, Khateeb MI. Evaluation of ELISA in the diagnosis of acute and chronic brucellosis in human beings. $J$ Hyg 1986; 97: 457-469.

27. Ariza J, Pellicer T, Pallarés R, Foz A, Gudiol F. Specific antibody profile in human brucellosis. Clin Infect Dis 1992; 14: $131-140$

28. Goldbaum FA, Morelli L, Wallach J, Rubbi CP, Fossati CA. Human brucellosis: immunoblotting analysis of three Brucella abortus antigenic fractions allows the detection of components of diagnostic importance. Medicina B. Aires 1991; 51: 227 232.

29. Report. Joint FAO/WHO Expert Committee on Brucellosis, 6th report. WHO Tech Rep Ser 1986; No. 740. Geneva, WHO.

30. Ariza J, Gudiol F, Pallarés R, Rufi G, Fernández-Viladrich P. Comparative trial of rifampin-doxycycline versus tetracyclinestreptomycin in the therapy of human brucellosis. Antimicrob Agent Chemother 1985; 28: 548-551.

31. Akova M, Uzun Ö, Akalin HE, Hayran M, Ünal S, Gür D. Quinolones in the treatment of human brucellosis; comparative trial of ofloxacin-rifampin versus doxycycline-rifampin. Antimicrob Agents Chemother 1993; 37: 1831-1834.

32. Crawford RM, Van de Verg L, Yuan L et al. Deletion of purE attenuates Brucella melitensis infection in mice. Infect Immun 1996; 64: 2188-2192. 